\title{
EFFECT OF FEEDING BUFFALOES ON DIETS CONTAINING VEGETABLE OILS RICH IN UNSATURATED FATTY ACIDS ON ITS PRODUCTIVE PERFORMANCE AND MILK QUALITY.
}

\author{
A.M. Kholif, A.F. Sayed, M. Abd El Aziz, G. Gouda and Hoda Alzahar \\ Department of Dairy Science, National Research Center, Cairo, Egypt.
}

(Received 26/11/2019, accepted 26/1/2020)

\section{SUMMARY}

$\mathrm{F}$ our lactating buffalos with an average weight of $515 \mathrm{~kg}$ were randomly assigned to four experimental groups in a $4 \times 4$ Latin Square design experiment with repeated measures in time for 16 weeks (4 treatments and four experimental periods).Each group received one of the following four dietary treatments:1- Control ration(fed a basal diet of berseem clover and concentrates (60:40 DM basis), 2- flax group (fed the control diet $+2 \%$ flaxseed oil), 3 - soya group (fed the control diet $+2 \%$ soybean oil) and 4- flax \& soya group (fed the control diet $+2 \%$ soybean oil plus flaxseed oil $(1: 1 \mathrm{v} / \mathrm{v})$ ). The results showed that the supplementation of buffaloes' diets with soybean, flaxseed oils or mix-oils had no negative effects on total dry matter intake. Concerning blood serum parameters, flax group had highest values of serum TP, albumin, glucose, triglycerides, cholesterol (HDL, LDL), creatinine, and GOT, while soybean oil treated group recorded the highest values of serum cholesterol, AG ratio, (GPT) and urea-N followed by flax group then flax+soya group. The flax group recorded the highest values of daily milk yield $(8.55 \mathrm{~kg} / \mathrm{h} / \mathrm{d}), \mathrm{F} \mathrm{C}$ $\mathrm{M}$ yield $(12.71 \mathrm{~kg} / \mathrm{h} / \mathrm{d})$ and fat content $(7.24 \%)$, while soya oil treatment recorded the highest values of total solids $(19.10 \%)$, solids not fat $(12.04 \%)$, protein $(4.91 \%)$, lactose $(6.16 \%)$ and ash content $(1 \%)$. Control group revealed the lowest values of total solids $(17.73 \%)$, fat content $(6.64 \%)$, solids not fat $(11.09 \%)$, lactose $(5.71 \%)$. Flaxseed group recorded the highest values of all milk constituents yield except total protein yield followed by soya group, then flax + soya group, while control group recorded the lowest values. Fatty acids in milk showed that $\mathrm{C}_{16: 0}$ was higher in control diet than treated diets. Stearic acid $\left(\mathrm{C}_{18: 0}\right), \mathrm{C}_{18: 4}, \mathrm{C}_{20: 0}$ and $\mathrm{C}_{20: 1}$ revealed higher values with treated diets than control. At the same time, treatment with soya or mixture of soya and flax oil showed higher values for $\mathrm{C}_{18: 2}$ than control or flax treated animals. It could be concluded that adding vegetable oils to buffaloes diet enhanced milk yield and fat content and $\mathrm{C}_{18: 0}, \mathrm{C}_{18: 4}, \mathrm{C}_{20: 0}$ and $\mathrm{C}_{20: 1}$, however, treatment with soya or mixture of soya and flax oil showed higher values for $\mathrm{C}_{18: 2}$ than control or flax treated animals.

Keywords: Lactating buffaloes, milk yield and composition, flaxseed oil, soybean oil and serum parameters

\section{INTRODUCTION}

Buffaloes' milk considers nearly twice as rich in fat and about $30 \%$ higher in total solids than cow milk. Recent research has shown that fatty acids (FAs) may modulate immune responses in several species including cows. Addition of FAs to dairy cow diets has become common practice in an effort to increase the energy density of the diet to prevent the state of negative energy balance (NEB) that usually accompanies the transition period of these animals. Development of new feeding strategies in which dietary fats influence the immune responses. So we can increase the amount of milk production and enhance the reproductive performance by improving reproductive tract immunity and decreasing stress and inflammatory media to postpartum especially during the summer season in Egypt which cause huge losses.

Flaxseed oil and soybean oil are excellent sources of $\mathrm{C}_{18: 3}, \mathrm{C}_{18: 2}$, omega-3 FA and omega-6 FAs; however, feeding high levels of plant oils can negatively affect ruminal fermentation (Onetti et al., 2001). Dietary oil or oilseed supplementation increases the concentrations of trans fatty acids in milk (Abo El-Nor and Khattab, 2012; and Morsy et al., 2015), resulting in healthier milk for humans. Inclusion of crushed flaxseed or flaxseed oil in the diet did not affect the DM intake or serum concentrations of total protein, albumin, globulin, albumin/globulin ratio, urea-N, GPT, GOT and creatinine. While increased milk production, total solids, solids not fat and lactose (Kholif et al. 2018). 
Supplementation of dairy cows (Benchaar et al. 2012) and goats' diets (Kholif et al. 2016) with flaxseed oil did not affect feed intake. The effects of level and type of fat supplements on feed intake are negligible when total fat concentration is below 6\% of the DM (Dhiman et al. 2000 and Petit 2002). The effect of oil sources differing in linoleic or linolenic acid concentrations on feed utilization, milk yield and composition. Therefore, the current study was conducted to assess the effect of feeding soybean (rich in linoleic acid) and/or flaxseed (rich in linolenic acid) oils at $2 \%$ of daily feed intake soybean oil plus flaxseed oil $(1: 1 \mathrm{v} / \mathrm{v})$ for 16 weeks on feed utilization, blood chemistry, milk yield and composition.

\section{MATERIALS AND METHODS}

Animals were cared and handled at private farm in Embaba, Giza Governorate and the laboratories of Dairy Animal Production and Dairy Chemistry, National Research Centre (Egypt) during winter of 2018.

\section{Animals, feeding and experimental design:}

Four lactating buffalos of about $515 \mathrm{~kg}$ of body weight were randomly assigned to four experimental groups in a $4 \times 4$ Latin Square Design experiment with repeated measures in time for 16 weeks (4 treatments and four experimental periods). The buffalos were housed individually in soil-surfaced tie stalls $\left(4.0 \mathrm{~m}^{2} /\right.$ animal), under shade, without any bedding and with free access to water and diets. The experimental diets were formulated to meet their nutrient requirements according to NRC (2000) recommendations. The basal diet was fed to the animals which contained per $\mathrm{kg}$ (as dry matter basis): $600 \mathrm{~g}$ of Egyptian berseem clover (Trifolium alexandrinum) and $400 \mathrm{~g}$ of concentrates feed mixture.

As recommended by the results of previous research (Ye et al., 2009; and Morsy et al., 2015) and to prevent negative effect of feeding high levels of plant oil (e.g., decreased feed intake and fiber digestion), animals were fed the basal diet (control) or the basal diet supplemented at $2 \%$ of daily feed intake with soybean oil, flaxseed oil, or soybean oil plus flaxseed oil at $1: 1 \mathrm{v} / \mathrm{v}$ for 16 weeks. The oils were store at room temperature and mixed with the concentrate portion of diets once daily and fed individually two times a day at 08:00 and 16:00 $\mathrm{h}$ in two equal portions. Feed samples of berseem clover and concentrate feed mixture were took daily, composite weekly and were dried at $60{ }^{\circ} \mathrm{C}$ in a forced-air oven for $48 \mathrm{~h}$. and were ground to pass a 1-mm screen using a Wiley mill, after which the ground samples were store for chemical analyses. Ingredient and chemical composition of total mixed ration of experimental lactating buffaloes (DM basis) are listed in (Table 1).

Table (1): Ingredient and chemical composition of total mixed ration of experimental lactating buffaloes (DM basis).

\begin{tabular}{lccc}
\hline Item & Berseem & CFM* & TMR** \\
\hline Roughage : Concentrate ratio & 0.6 & 0.4 & 1.0 \\
Chemical composition (g/100 g DM) & & & \\
Dry matter & 91.18 & 91.41 & 91.27 \\
Ash & 11.61 & 14.85 & 12.90 \\
Organic matter & 88.39 & 85.15 & 87.10 \\
Crude protein & 12.25 & 15.89 & 13.71 \\
Ether extract & 2.89 & 5.04 & 3.75 \\
Crude fiber & 23.22 & 15.12 & 19.98 \\
NFE & 50.03 & 49.10 & 49.66 \\
\hline
\end{tabular}

${ }^{*}$ Concentrate feed mixture (CFM) consisted of crushedyellow corn, cotton seed meal,wheat bran,calcium carbonate, minerals and vitaminsand common salt (50:25:20:2:2:1)

${ }^{* *} T M R=$ Total Mixed Ration

Soybean oil, flak seed oil or mix of two oils (1:1) were added to ration as $2 \%$ of DM intake (about $300 \mathrm{~g} / \mathrm{d}$.). Minerals and Vitamins: Contained $141 \mathrm{~g} / \mathrm{kg}$ of $\mathrm{Ca}, 27 \mathrm{~g} / \mathrm{kg}$ of $\mathrm{P}, 65 \mathrm{~g} / \mathrm{kg}$ of $\mathrm{Mg}, 14 \mathrm{~g} / \mathrm{kg}$ of S, $120 \mathrm{~g} / \mathrm{kg}$ of $\mathrm{Na}, 6 \mathrm{~g} / \mathrm{kg}$ of K, $944 \mathrm{mg} / \mathrm{kg}$ of Fe, $1613 \mathrm{mg} / \mathrm{kg}$ of Zn, $484 \mathrm{mg} / \mathrm{kg}$ of Cu,1748mg of Mn, 58mg/kg of I, $51 \mathrm{mg} / \mathrm{kg}$ of Co, $13 \mathrm{mg} / \mathrm{kg}$ of Se, 248,000 U/kg of vitamin A, 74,000 UI/kg of vitamin D3 and 1656 IU/kg of vitamin E.

\section{Chemical analysis:}

Dried feed samples were ground to pass a 1-mm screen using a Wiley mill (Arthur H. Thomas, Philadelphia, PA, USA), and analyzed for DM (method 930.15), ash (method 942.05), N (method 954.01) and ether extract according to AOAC (2010) official methods. 


\section{Sampling and analysis of blood serum:}

On the last day of each experimental period, $10-\mathrm{mL}$ blood samples were taken $4 \mathrm{~h}$ after feeding from the jugular vein of each animal into a clean dry tube, without anticoagulants. Blood samples were centrifuged at 4,000 $\times g$ for $20 \mathrm{~min}$. Serum was separated into 2-mL Eppendorf tubes and frozen at -20 ${ }^{\circ} \mathrm{C}$ until analysis. Blood serum samples analyzed for concentrations of total protein, albumin, urea-N, glutamate-oxaloacetate transaminase (GOT), glutamate-pyruvate transaminase (GPT), glucose, creatinine (Cr), cholesterol, triglycerides, low-density lipoprotein cholesterol (LDL) and high-density lipoprotein cholesterol (HDL), using specific kits following manufacturer instructions. Globulin concentration calculated by subtracting albumin values from their corresponding total protein values.

\section{Milk sampling and milk composition:}

Milk production was determined at the last week of each experimental period ( 5 days as a collection period). Animals were hand milked twice daily at 09:00 and 21:00 and samples $(100 \mathrm{~g} / \mathrm{kg}$ of recorded milk yield) were collected at each milking. A mixed sample of milk (proportional to amounts produced in the morning and evening) were take daily. Milk samples were analyzed for total solids, fat, protein, and lactose using Milkotester (Bulgaria) (Model mastereco milk analyzer S/NO: 22646). The ash content of milk was determining after heating a milk sample in a muffle furnace at $550{ }^{\circ} \mathrm{C}$ for $8 \mathrm{~h}$. The fatty acid methyl ester was prepared according to the method of AOAC (2005). Fatty acid methyl esters were injected into HP 6890 series GC apparatus provided with a DB-23 column (60 m x $0.32 \mathrm{~mm}$ x $25 \mu \mathrm{m})$. Carrier gas was $\mathrm{N} 2$ with flow rate $2.2 \mathrm{~mL} / \mathrm{min}$, splitting ratio of 1:50. The injector temperature was 250 ${ }^{\circ} \mathrm{C}$ and that of Flame Ionization Detector (FID) was $300{ }^{\circ} \mathrm{C}$. The temperature setting was as follows: 150 ${ }^{\circ} \mathrm{C}$ to $210{ }^{\circ} \mathrm{C}$ min- 1 and then held at $210{ }^{\circ} \mathrm{C}$ for 25 min. peaks were identified by comparing the retention times obtained with standard methyl esters.

\section{Statistical analyses:}

Data were analyzed using the procedure of SAS (SAS, 2004). Duncan test was used to separate the effect of means (Duncan, 1955).

\section{RESULTS AND DISCUSSION}

\section{Feed intake:}

The present results in Table (3) indicated that no differences were found among treated groups in dry matter intake $(\mathrm{kg} / \mathrm{h} / \mathrm{d})$ by using plant oils in the diet of lactating buffaloes, which indicates that the palatability of the diets was not affected by the soybean oil, flaxseed oil or mix of both. Benchaar et al. (2012) and Kholif et al. (2016) observed that supplementation of dairy cows and goats' diets with flaxseed oil, respectively, did not affect feed intake. Similarly, Morsy et al. (2015) found that feed intake did not affected by feeding sunflower oil or whole seeds to lactating Damascus goats. In our study, the oil supplementation was approximately $2 \%$ of the feed intake which is not high enough to depress the intake because it is below the safe level for ruminal microflora activity (Morsy et al. 2015 and Kholif et al. 2016). Dhiman et al. (2000) and Petit (2002) noted that the effects of level and type of fat supplements on feed intake are negligible when total fat concentration is below $6 \%$ of the DM.

\section{Blood serum:}

Data of Table (2) showed that flaxseed oil treated group had highest values of serum TP, Albumin, glucose, triglycerides, cholesterol (HDL and LDL), creatinine and GOT, while soybean oil treated group recorded the highest values of serum cholesterol, AG ratio, (GPT)and urea-N followed by flaxseed group then flax-soya treated group. However, control group revealed the highest value globulin and the lowest values of serum albumin, AG ratio, cholesterol (HDL and LDL), GPT, GOT, creatinine and urea-N. A significantly $(\mathrm{P}<0.05)$ higher values were detected for only the serum albumin, globulin, A/G ratio, glucose, triglycerides, and urea-N. All measured blood metabolites were within the reference ranges reported by Boyd (2011). Values of serum GPT, GOT and creatinine indicated that feeding plant oils had no negative effect on liver function and kidney function, also, it had the lower contents of triglycerides (except flaxseed oil) avoiding that hazards of heart disease. Data also showed that the benefit effect of flaxseed oil to increase serum values of TP, albumin, glucose and HDL. These increases might be due to the higher bypass protein supplied from linseed diet and lower stress due to the antiinflammatory effect of omega 3 in flaxseed oil treated animals (Amaral et al., 2008). 


\section{Kholif et al.}

Table (2): Effect of soybean and/or flaxseed oil on buffaloes' blood serum parameters.

\begin{tabular}{lccccc}
\hline Item & Control & Flax & Soya & Flax-soya & S.E. \\
\hline GOT (U/l) & 37.63 & 42.60 & 39.88 & 41.93 & 0.97 \\
GPT (U/l) & 13.25 & 16.15 & 17.25 & 14.78 & 0.81 \\
Glucose (mg/dl) & $42.01^{\mathrm{a}}$ & $54.31^{\mathrm{a}}$ & $35.00^{\mathrm{b}}$ & $43.12^{\mathrm{a}}$ & 0.13 \\
TriGlyc. (mg/dl) & $35.93^{\mathrm{a}}$ & $40.37^{\mathrm{a}}$ & $24.45^{\mathrm{b}}$ & $23.52^{\mathrm{b}}$ & 0.60 \\
Chol (mg/dl) & 117.67 & 151.08 & 159.05 & 143.97 & 2.06 \\
HDL (mg/dl) & 88.27 & 107.72 & 93.90 & 88.01 & 1.01 \\
LDL (mg/l) & 15.90 & 35.15 & 18.18 & 30.73 & 0.41 \\
TP (mg/dl) & 6.68 & 7.32 & 6.20 & 5.81 & 0.22 \\
Alb. (mg/dl) & $2.73^{\mathrm{b}}$ & $3.58^{\mathrm{a}}$ & $3.14^{\mathrm{ab}}$ & $2.97^{\mathrm{a}}$ & 0.28 \\
Glob. (mg/dl) & $3.95^{\mathrm{a}}$ & $3.74^{\mathrm{ab}}$ & $3.06^{\mathrm{b}}$ & $2.84^{\mathrm{b}}$ & 0.22 \\
AG ratio & $0.88^{\mathrm{b}}$ & $1.00^{\mathrm{ab}}$ & $1.04^{\mathrm{ab}}$ & $1.05^{\mathrm{a}}$ & 0.15 \\
Urea (mg/dl) & $59.73^{\mathrm{c}}$ & $81.51^{\mathrm{a}}$ & $95.11^{\mathrm{a}}$ & $75.61^{\mathrm{ab}}$ & 4.11 \\
Cr $(\mathrm{mg} / \mathrm{l})$ & 1.18 & 1.42 & 1.33 & 1.21 & 0.12 \\
\hline S.E. & & & & 1.42 & \\
\hline
\end{tabular}

S.E. = Standard error, GOT = Glutamic-oxaloacetic transaminases, $G P T=$ Glutamic-pyruvic transaminases. TriGlyc. $=$ Triglycerides, Chol. $=$ Cholesterol, $H D L=$ High density lipoprotein, $L D L=$ Low density lipoprotein, TP



\section{Milk yield and composition:}

Data of Table (3) indicated that animals received flaxseed oil recorded the highest values $(\mathrm{P}>0.05)$ of milk yield $(8.55 \mathrm{~kg} / \mathrm{h} / \mathrm{d}), \mathrm{FCM}$ yield $(12.71 \mathrm{~kg} / \mathrm{h} / \mathrm{d})$ and fat content $(7.24 \%)$, while soya oil treatment recorded the highest values of total solids $(19.10 \%)$, solids not fat $(12.04 \%)$, protein $(4.91 \%)$, lactose $(6.16 \%)$ and ash content $(0.97 \%)$, control group revealed the lowest values of total solids $(17.73 \%)$, fat content $(6.64 \%)$, solids not fat $(11.09 \%)$, lactose $(5.71 \%)$ and ash content $(0.96 \%)$. Also the ash content and milk $\mathrm{pH}$ showed no differences $(\mathrm{P}>0.05)$ among all treated groups. Data indicated that flaxseed oil, soy oil and flax-soya treated animals had higher FCM yield values $(12.71,11.92$ and $11.63 \mathrm{~kg} / \mathrm{d}$., resp.) than that of control animals $(11.6 \mathrm{~kg} / \mathrm{d})$. Data also revealed that (flaxseed) group had higher fat-corrected milk yield value by about $9.6 \%$ than control group ,In general adding plant oils to the diets of lactating buffaloes increasing milk constituents but flaxseed group only increased milk yield in this study.

The results of milk production in this study were in the line of Cortes et al. (2010) when used whole flaxseed, or Caroprese et al. (2010) when used flaxseed oil. Similar results were also recently noted by Neveu et al. (2014). These results are conflict with the findings of other studies, which found a reduction in milk production (Petit et al., 2005) or higher milk production as a result of linseed oil or crushed linseed (Kholif et al. 2015), and extruded linseed (Gomez-Cortes et al. 2009 and Kholif et al. 2011), flaxseed oil, soy oil or mix of both (Kholif et al. 2016) and linseed oil (Benchaar et al. 2012). An increase in milk production may be due to higher bypass protein supplied from linseed diet and lower stress due to the anti-inflammatory effect of omega3 in flaxseed oil treated animals (Amaral et al.,2008) .Also,the relative improvement in milk production by feeding of linseed oil might be due to the higher serum glucose values recoded by flaxseed oil treated animals (Table 2) .Milk produced from buffaloes fed flaxseed contained higher fat contents compared to control sample. The same results were found by Dhiman et al. (2000) who mentioned that feeding fat through seeds maintains or increases milk fat content. These increases of milk fat content could be attributed to the higher serum triglycerides and cholesterol values recoded by flaxseed oil treated animals (Table 2).

Total solids content in milk from buffaloes fed flaxseed was slightly increased compared to the control sample which may be due to the higher fat and lactose contents.. However, the pH values did not change in both milk samples (Foda et al. 2012). The positive effects of flaxseed oil supply on milk protein content is a relevant result as this parameter not only affects milk price but also determines the speed and quality of coagulation in cheese production (Antonacci et al. 2017). These increases might be due to the higher serum total protein and Albumin values (Table 2). In confined production systems, supplementation with unprotected lipids often decrease milk protein content (Morand-Fehr et al. 1986, Gagliostro and Chilliard, 1992 and Palmquist et al., 1993). Other studies have reported that oils supplementation did not affect either milk fat (Gonthier et al., 2005) or protein concentration (Petit et al., 2004 and Martin et al., 2008). 
Table (3): Milk yield and composition (\%) of lactating buffaloes fed a basal diet supplemented with soybean and/or flaxseed oils.

\begin{tabular}{|c|c|c|c|c|c|}
\hline \multirow[t]{2}{*}{ Item } & \multicolumn{4}{|c|}{ Treatment $^{1}$} & \multirow[t]{2}{*}{ SEM } \\
\hline & Control & Flax & Soya & FlaxSoya & \\
\hline Dry matter intake $(\mathrm{kg} / \mathrm{h} / \mathrm{d})$. & 12.92 & 12.91 & 12.90 & 12.88 & 0.88 \\
\hline Milk yield $(\mathrm{kg} / \mathrm{h} / \mathrm{d})$ & 8.31 & 8.55 & 8.17 & 8.25 & 0.21 \\
\hline F C M yield (kg/h/d) & 11.6 & 12.71 & 11.92 & 11.63 & \\
\hline Milk pH & 6.69 & 6.69 & 6.78 & 6.75 & 0.02 \\
\hline Total solids & 17.73 & 18.74 & 19.10 & 18.35 & 0.70 \\
\hline Solids not fat & 11.09 & 11.50 & 12.04 & 11.62 & 0.19 \\
\hline Fat & 6.64 & 7.24 & 7.06 & 6.73 & 0.71 \\
\hline Protein & 4.42 & 4.38 & 4.91 & 4.49 & 0.07 \\
\hline Lactose & 5.71 & 6.15 & 6.16 & 6.13 & 0.12 \\
\hline Ash & 0.96 & 0.98 & 0.97 & 1.00 & 0.02 \\
\hline \multicolumn{6}{|c|}{$\begin{array}{l}{ }^{I} \text { The basal diet based on } 400 \mathrm{~g} \text { of concentrates feed mixture } / \mathrm{kg} D M \text { and } 600 \mathrm{~g} \text { berseem clover (Trifolium } \\
\text { alexandrinum)/kg DM without addition of oil (Control) or with addition of } 300 \mathrm{ml} \text { of soybean oil (Soya), } 300 \mathrm{ml} \text { of } \\
\text { flaxseed oil (Flax), or } 300 \mathrm{ml} \text { of soybean }+ \text { flaxseed oil }(1: 1 \mathrm{v} / \mathrm{v}) / \text { goat } / \mathrm{d} \text { (FlaxSoy). } \\
\text { SEM = Standard error mean, Flax = Flaxseed oil treatment, Soy = Soybean oil treatment, FlaxSoy = Flaxseed oil }+ \\
\text { Soybean oil treatment. FCM }=0.4 \text { (Milk Yield) }+15 \text { (Fat Yield) } \\
\text { All values are not significant at } 5 \% \text { level. }\end{array}$} \\
\hline
\end{tabular}

\section{Fatty acids profile in milk:}

Data in Table (4) shows the effect of soybean and/or flaxseed oil on buffaloes' milk fatty acids profile. It was remarked that were insignificants between treatments concerning all short-chain fatty acids (C4:0-C12:0), while $\mathrm{C} 16: 0$ as a medium-chain fatty acid was higher in control diet than treated diets. Stearic acid (C18:0), C18:4, C20:0 and C20:1 revealed higher values with treated diets than

Table (4): Effect of soybean and/or flaxseed oil on buffaloes' milk fatty acids.

\begin{tabular}{cccccc}
\hline Fatty acid $(\%)$ & \multicolumn{5}{c}{ Treatment } \\
\cline { 2 - 5 } & Control & Flax & Soya & Flax Soya & S.E. \\
\hline C4:0 & 3.79 & 3.54 & 2.26 & 2.85 & 1.40 \\
C6:0 & 1.77 & 1.48 & 1.03 & 1.22 & 0.90 \\
C8:0 & 0.76 & 0.58 & 0.44 & 0.48 & 0.09 \\
C10:0 & 1.26 & 0.97 & 0.83 & 0.86 & 0.29 \\
C13:0 & 1.80 & 1.46 & 1.33 & 1.39 & 0.13 \\
C14:0 & 0.07 & 0.06 & 0.05 & 0.06 & 0.02 \\
C14:1 & 7.78 & 7.11 & 7.14 & 7.13 & 0.31 \\
C15:0 & 0.38 & 0.23 & 0.29 & 0.27 & 0.11 \\
C15:1 & 1.16 & 1.05 & 1.10 & 1.08 & 0.05 \\
C16:0 & 0.30 & 0.28 & 0.28 & 0.28 & 0.02 \\
C16:1 & $27.86^{\mathrm{a}}$ & $22.35^{\mathrm{b}}$ & $21.85^{\mathrm{b}}$ & $22.10^{\mathrm{b}}$ & $0.15^{*}$ \\
C17:0 & 1.26 & 0.93 & 0.92 & 0.92 & 0.05 \\
C17:1 & 0.82 & 0.75 & 0.77 & 0.77 & 0.08 \\
C18:0 & 0.25 & 0.19 & 0.22 & 0.21 & 0.04 \\
C18:1 & $15.41^{\mathrm{b}}$ & $19.49^{\mathrm{a}}$ & $17.98^{\mathrm{a}}$ & $18.73^{\mathrm{a}}$ & $0.16^{*}$ \\
C18:2T & 27.65 & 31.43 & 34.49 & 32.95 & 0.66 \\
C18:2 & 0.81 & 1.15 & 1.27 & 1.23 & 0.02 \\
C18:3 & $1.91^{\mathrm{b}}$ & $1.85^{\mathrm{b}}$ & $2.17^{\mathrm{a}}$ & $2.02^{\mathrm{a}}$ & $0.04^{*}$ \\
C18:4 & $0.29^{\mathrm{b}}$ & $0.53^{\mathrm{a}}$ & $0.41^{\mathrm{a}}$ & $0.44^{\mathrm{a}}$ & $0.02^{*}$ \\
C20:0 & $0.99^{\mathrm{b}}$ & $1.21^{\mathrm{a}}$ & $1.98^{\mathrm{a}}$ & $1.62^{\mathrm{a}}$ & $0.02^{*}$ \\
C20:1 & $0.32^{\mathrm{b}}$ & $0.44^{\mathrm{a}}$ & $0.41^{\mathrm{a}}$ & $0.43^{\mathrm{a}}$ & $0.01^{*}$ \\
C22:0 & $0.21^{\mathrm{b}}$ & $0.27^{\mathrm{a}}$ & $0.28^{\mathrm{a}}$ & $0.27^{\mathrm{a}}$ & $0.01^{*}$ \\
Total unknown & 0.16 & 0.16 & 0.18 & 0.17 & 0.01 \\
\hline and b superscripts at the same row means & 2.43 & 2.28 & 2.55 & 0.30 \\
\hline
\end{tabular}

$a$ and $b$ superscripts at the same row means significant at 5\% level. * Means significant at $5 \%$ level. 


\section{Kholif et al.}

control. At the same time, treatment with soya or mixture of soya and flax oil showed higher values for C18:2 than control or flax treated animals. The data of El-Sherbiny et al. (2015) agreed with these results. Also, AbuGazaleh and Holmes (2007) reported that the concentration of cis-9, trans-11CLA and vaccenic acid in milk fat were higher for cows fed oil-supplemented diets over 8 weeks of oil supplementation.

\section{CONCLUSION}

It could be concluded that adding vegetable oils to buffaloes diet enhanced milk yield and fat content and C18:0, C18:4, C20:0 and C20:1, however, treatment with soya or mixture of soya and flax oil showed higher values for C18:2 than control or flax treated animals. Additional studies, including in vitro and in vivo experiments, are recommended to investigate the inclusion of flaxseed oil, soybean oil or mix of both at varying concentrations on lactation performance.

\section{ACKNOWLEDGMENT}

The authors thank National Research Centre for supporting this work through the project No. 11030156.

\section{REFERENCES}

Abo El-Nor, S.A.H. and M.S., Khattab (2012). Enrichment of milk with conjugated linoleic acid by supplementing. Pakistan J. Biol. Sci. 15, 690-693.

Abu-Gazaleh, A.A. and L.D. Holmes (2007). Diet supplementation with fish oil and sunflower oil to increase conjugated linoleic acid levels in milk fat in partially grazing diary cows.J. Dairy Sci., 90: 2897-2904.

Amaral, B.C.; C.R. Staples; O.S.A. Filho; T.R. Bilby; J. Block; F. Silvestre; F.M Cullens; P.J. Hansen, and W.W. Thatcher (2008): Effect of supplemental fat source on production, Immunity, and reproduction of peri parturient Holstein cows in summer. J. Dairy Sci., 88 (Suppl. 1): 178.

Antonacci, L.E., G.A. Gagliostro , A.V. Cano and C.A. Bernal (2017). Effects of Feeding Combinations of Soybean and Linseed Oils on Productive Performance and Milk Fatty Acid Profile in Grazing Dairy Cows. Agricultural Sciences, 8: 984-1002.

AOAC (2005). Official Methods of Analysis (17th ed.). Gaitherburg, MD: AOAC International.

AOAC (2010). Official Methods of Analysis. (19 th $^{\text {th }}$ Edition), Published by the Association of Official Analytical Chemists, Arlington, Virginia, USA.

Benchaar, C., G.A. Romero-Pérez, P.Y. Chouinard, F. Hassanat, M. Eugene, H.V. Petit and C. Côrtes (2012). Supplementation of increasing amounts of linseed oil to dairy cows fed total mixed rations: Effects on digestion, ruminal fermentation characteristics, protozoal populations, and milk fatty acid composition. J Dairy Sci., 95: 4578-4590.

Boyd, J.W. (2011). The interpretation of serum biochemistry test results in domestic animals. In: 429 Veterinary Clinical Pathology, Merck Sharp \&Dohme Corp., a subsidiary of Merck \& Co., Inc

Caroprese, M., A. Marzano, R. Marino, G. Gliatta, A. Muscio, A. Sevi (2010). Flaxseed supplementation improves fatty acid profile of cow milk. J. Dairy Sci., 93: 2580-2588.

Côrtes, C., D.C. da Silva-Kazama, R. Kazama, N. Gagnon, C.R. Benchaa, G.T.D. Santos, L.M. Zeoula and H.V. Petit (2010). Milk composition, milk fatty acid profile, digestion, and ruminal fermentation in dairy cows fed whole flaxseed and calcium salts of flaxseed oil. J. Dairy Sci., 93: 3146-3157.

Dhiman, T.R., L.D. Satter, M.W. Pariza, M.P. Galli, K. Albridht, M.X. Tolosa (2000). Conjugated linoleic acid (CLA) content of milk from cows offered diets rich in linoleic and linolenic acid. J Dairy Sci., 83: 1016-1027. 
Duncan, D.B. (1955). Multiple range and multiple F tests. Biometrics, 11: 1-42.

El-Sherbiny, M.A., S.A.H. Abo El-Nor and Ahlam A. El-Shewy (2015). Egyptian buffaloes milk fatty acids affected by vegetable oils feeding: "Using sunflower oil, olive oil and their blend in lactating buffaloes diets to modulate the milk fatty acid content". LAP LAMBERT Academic Publishing Germany, ISBN: 978-3-659-69410-3.

Foda, M.I., S.M. Kholif, S.H.S. Mohamed and T.A. Morsy (2012). Evaluation of ground flaxseed supplementation to lactating buffaloes ration versus control milk samples for milk and stirred yoghurt production. J. Life Sci., 4(1): 11-18

Gagliostro, G.A. and Y. Chilliard (1992). Use of protected lipids in dairy cow nutrition. I. Effects on the production and composition of milk, and on intake of dry matter and energy. Revista Argentina de Producción Animal. 12, 1-15.

Gomez-Cortes, P., A. Bach, P. Luna, M. Juarez, M.A. de la Fuente (2009). Effects of extruded linseed supplementation on n-3 fatty acids and conjugated linoleic acid in milk and cheese from ewes. J Dairy Sci., 92: 4122-4134.

Gonthier, C., A.F. A.F. Mustafa, D.R. Ouellet, R. Berthiaume and H.V. Petit (2005). Feeding micronized and extruded flaxseed to dairy cows: Effects on blood parameters and milk fatty acid composition. J. Dairy Sci. 88, 748-756.

Kholif, A.E., T.A. Morsy, A.M. Abd El Tawab, U.Y. Anele and M.L. Galyean (2016). Effect of Supplementing diets of lactating Anglo-nubian goats with soybean and flaxseed oils on lactational performance. J. Agric. Food Chem., 64(31): 6163-6170

Kholif, A.E., T.A. Morsy and M.M. Abdo (2018). Crushed flaxseed versus flaxseed oil in the diets of Nubian goats: Effect on feed intake, digestion, ruminal fermentation, blood chemistry, milk production, milk composition and milk fatty acid profile, Animal Feed Science and Technology, 244, $66-75$

Kholif, S.M., T.A. Morsy, A.A. Abedo, N. El-Bordeny and M.M. Abdo (2011). Milk production and composition, milk fatty acid profile, nutrients digestibility and blood composition of dairy buffaloes fed crushed flaxseed in early lactation. Egyptian J. Nutr.\& Feeds. 14, 385-394.

Kholif, S.M., T.A. Morsy, O.H. Matloup, H.M. Ebeid and A.M. Kholif (2015). Effects of Crushed Linseed or Linseed Oil Supplementation on performance of dairy goats and fatty acid profile in Milk.Life Science Journal. 12(2s), 94-99.

Martin, C., J. Rouel, J.P. Jouan, M. Doreau and Y. Chilliard (2008). Methane output and diet digestibility in response to feeding dairy cows crude linseed, extruded linseed, or linseed oil. J. Anim. Sci. 86: 2642-2650.

Morand-Fehr, P., Y. Chilliard and P. Bas (1986) Repercusions de l'Apport de matieres grasses dans la ration sur la production et la composition du lait de ruminant. [Impact of including fats in the ration on yield and composition of ruminant milk]. Institut National de la RechercheAgronomique. 64, 5972 .

Morsy, T.A. S.M. Kholif, A.E. Kholif, O.H. Matloup, A.Z.M. Salem and A. Abu Elella (2015). Influence of sunflower whole seeds or oil on ruminal fermentation, milk production, composition, and fatty acid profile in lactating goats. Asian Australas. J. Anim. Sci., 28: 1116-1122.

Neveu, C., B. Baurhoo and A. Mustafa (2014). Effect of feeding extruded flaxseed with different grains on the performance of dairy cows and milk fatty acid profile. J Dairy Sci., 97: 1543-1551.

NRC (2000).National Research Council.Nutrient requirements of cattle. 6th ed., National Academy of Science, Washington, DC.

Onetti, S.G., R.D. Shaver, M.A. McGuire, R.R. Grummer (2001). Effect of type and level of dietary fat on rumen fermentation and performance of dairy cows fed corn silage based diets. J. Dairy Sci. 84 2751-2759.

Palmquist, D.L., A.D. Beaulieu and D.M. Barbano (1993) Feed and animal factors influencing milk fat composition. Journal of Dairy Science 76: 1753-1771.

Petit, H.V. (2002). Digestion, milk production, milk composition, and blood composition of dairy 554 cows fed whole flaxseed. J. Dairy Sci., 85: 1482-90. 


\section{Kholif et al.}

Petit, H.V., C. Germiquet and D. LeBel (2004).Effect of feeding whole unprocessed sunflower seed and flaxseed on milk production, milkcomposition, and prostaglandin secretion in dairy cows. J. Dairy Sci., 87: 3889-3898.

Petit, H.V., M. Ivan and P.S. Mir (2005). Effects of flaxseed on protein requirements and N excretion of dairy cows fed diets with two protein concentrations. J Dairy Sci., 89: 1755-1764.

SAS (2004). Statistical Analysis System.SAS User's Guide Statistics.SAS Institute Inc. Editors, Cary, NC.

Ye, J.A., Wang, C., H.F. Wang, H.W. Ye, B.X. Wang, H.Y. Liu, Y.M. Wang, Z.Q. Yang and J.X. Liu (2009). Milk production and fatty acid profile of dairy cows supplemented with flaxseed oil, soybean oil, or extruded soybeans. Acta Agriculturae Scandinavica, Section A — Anim. Sci. 59: 121-129.

\section{تأثير تغذيه الجاموس علي علائق تحتوي زيوت نباتيه غنيه بالأحماض الدهنيه غير المشبعه علي أدائه الإنتاجي وجودة اللبن التين}

\section{عبد القادر محمود خليف و أحمد فاروق سيد أحمد ومحمود عبد العزيز وجوده جوده وهدي الزهار

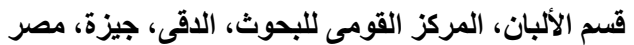

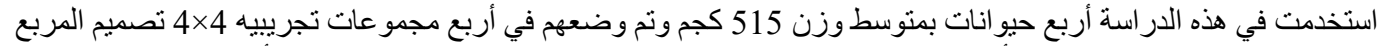

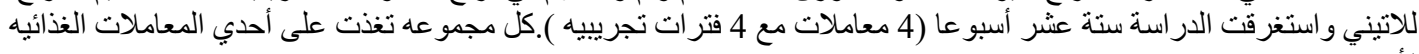
الأثبه:

1- مجوعة المقارنه (تغذت علي العليقه الاساسيه وهي مخلوط العلف المركز و البرسيم بنسبة 40: 60 2- مجمو عة الكتان (تغذت علي العليقه الاساسيه مضاف اليها زيت بذرة الكتان بنسبة 2\% من الماده الجافه المأكوله 3- مجمو عة الصويا(تغذت علي العليقه الاساسيه مضاف اليها زيت الصويا بنسبة 2\% 4- مجمو عة الكتان و الصويا (تغذت علي العليقه الاساسيه مضاف اليها مخلوط زيت الكتان و الصويا بنسبة 2\% 2.

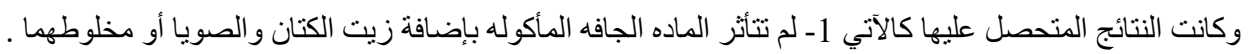

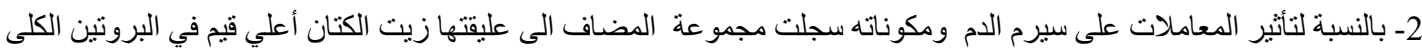

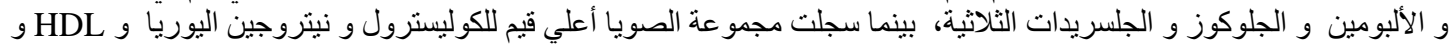
LDL و و و و الكرياتينين و مجمو عة الكتان+الصويا .

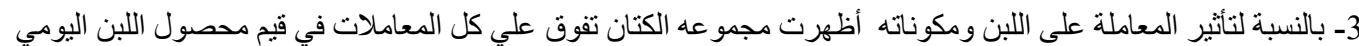

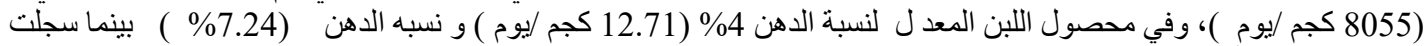

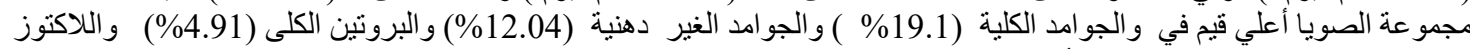

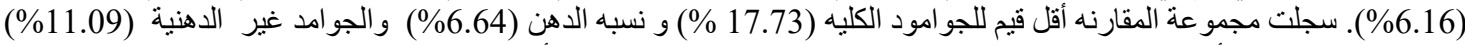

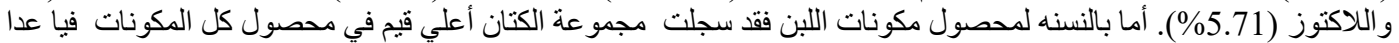

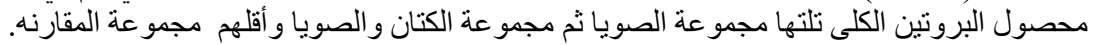

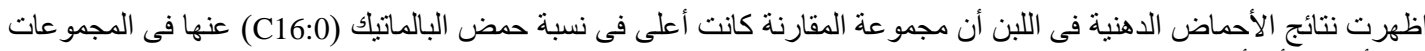

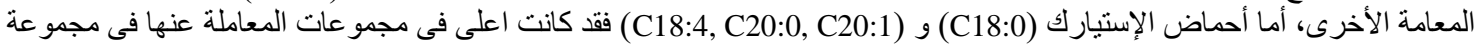

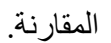
أظهرت المعاملة بزيت الصويا او خليط زيت الصويا مع زيت الكتان أعلى قيم لحمض الينولينك (C18:2) عنها فى المعاملة بزيت الكتان او مجمو عة المقارنة. و الخلاصة ان إضافة الزيوت النباتية الى علائق الجاموس الحابل تؤدى الى تحسين انتاج اللبن و نسبة الدهن به و كذلك نسب أحماض الإستيارك و اللينولنيك و ألأراشيدك و الأر اشيدونك.
} 